\title{
Antifungal activity of microbiological drugs in relation to pathogens from the genus Fusarium Link
}

\author{
Irina Astapchuk*, and Andrei Nasonov \\ Federal State Budget Scientific Institution «North Caucasian Federal Scientific Center of Horticulture, \\ Viticulture, Wine-making», str. 40 Let Pobedy, 39, Krasnodar, 350901, Russia
}

\begin{abstract}
As a result of studying the antifungal activity of biological drugs against fungi of the genus Fusarium, causative agents of rot of roots and fruits of the apple tree, both weak and very strong mycoparasitism were noted, but in most variants of the experiment, competition for area of nutrition prevailed. Under the influence of some drugs, the shape, edge and color of the fungus colony changed. In general, for the entire sample of pathogens, the best bioagents were antagonists of the drug Trichocin, WP, which suppressed all 5 strains with Biological efficiency (BE) 50-90 \% and showed hyperparasitism in 1 strain; and the drug Alirin B, WP, which inhibited the growth of 3 strains with BE 56-85\%, showing antibiosis or fungistatic antibiotic antagonism with the formation of a "sterile" zone.
\end{abstract}

\section{Introduction}

Fusarium is a widespread disease of agricultural crops all over the world, the causative agents of which, fungi of the genus Fusarium Link, infect more than 200 species of cultivated and wild plants: cereals, legumes, oilseeds, fruits, berries, etc. [1-5]. As you know, fungi of the genus Fusarium are capable of producing mycotoxins, and therefore they can lead to the death of a whole plant.

In the last 15 years, the prevalence of pathogens of this species has increased in the gardens of the Krasnodar Region; they are found both in the root rot pathocomplex and in the apple core rot pathocomplex. To protect against fusarium, fungicides of various origins are used. Currently, there are no fungicides registered in the Russian Federation to control fusarium root rot and apple core rot. In 2020-2021 we conducted a study of the effectiveness of chemical fungicides registered on an apple tree for the control of scab and powdery mildew against pathogens of rot of the core of apple fruits from the genus Fusarium Link in laboratory conditions. Fungicide Cidely-Top, DC (125 g/l difenoconazole $+15 \mathrm{~g} / \mathrm{l}$ ciflufenamide) inhibited the growth of fungi $F$. sporotrichioides, F. semitectum and $83 \%$ F. oxysporum by $95-96 \%$. The drug Score, CE (250 g/l difenoconazole) was less effective: it inhibited the growth of $F$. solani and $F$. semitectum by $72 \%$. Luna Tranquility, SC (125 g/1 fluopyram $+375 \mathrm{~g} / \mathrm{l}$ pyrimethanil) showed very high antifungal activity against $F$. avenacium, $F$. oxysporum species (100\%), but insufficient against $F$. solani (Mart.) Sacc.

* Corresponding author: irina astapchuk@mail.ru 
and F. semitectum Berk. \& Ravenel (21.9 and 24.0\%, respectively. The drug Tirada, SC $(400 \mathrm{~g} / 1$ thiram $+30 \mathrm{~g} / \mathrm{l}$ difenoconazole $)$ suppressed the growth of all studied micromycetes by $98-100 \%$. Granuflo, WDG ( $800 \mathrm{~g} / \mathrm{kg}$ thiram) and Chorus, WDG (750 g/kg cyprodinil) showed no sensitivity against $F$. solani (Mart.) Sacc. and F. semitectum Berk. \& Ravenel. $(17.3 ; 17.8 \%$ and $4.1 ; 6.6 \%$, respectively) $[6,7]$. Thus, our studies have shown that fungicides of chemical origin do not always show high efficiency of fusarium rot of the core of apple fruits. Currently, biological control in the plant protection system based on microbiological drugs is especially relevant in the world, as in the EU countries their share of use is $20 \%$, in North America $40 \%$ [8], in the Russian Federation - up to $15 \%$ [9]. In addition to the environmental component, the production of biofungicides based on living organisms is economically less expensive than chemical fungicides. Therefore, testing of biological products and a continuous search for promising bioagents against various plant diseases, including fusarium diseases, are constantly being conducted [9-17].

Thus, the addition of the culture liquid (CL) of Bacillus amyloliquefaciens to the medium significantly reduced the growth of the fungus Fusarium sporotrichioides and the formation of T-2 toxin in vitro [9]. In the literature, the results of screening are presented, promising strains of microbiological preparations were found, which showed a biological efficiency of $50 \%$ and higher in suppressing the causative agent of fusarium of roots of various cultures [18-20].

There is evidence that the biological drug Gliocladin-SC based on living cells of the fungus Trichoderma virens $3 \mathrm{X}$ has a fungicidal effect against pathogenic fungi, pathogens of fusarium root rot of wheat, corn, sunflower, pathogens that infect cabbage plants at all stages of development and during storage: R. solani, B. cinerea, Thielaviopsis basicola, Fusarium sp., Sclerotinia sclerotiorum [20].

In connection with the above, the study of the effectiveness of microbiological drugs in vitro against fungi of the genus Fusarium is promising and relevant. Objective of the study: to study the antifungal activity of microbiological drugs registered on an apple tree to control scab, powdery mildew, moniliosis, as well as promising, in relation to causative agents of rot of roots and cores of apple fruits from the genus Fusarium.

\section{Materials and methods}

The studies were carried out in 2020-2021 in the laboratory of biotechnological control of phytopathogens and phytophages Federal State Budget Scientific Institution «North Caucasian Federal Scientific Center of Horticulture, Viticulture, Wine-making». The objects of research were 5 monoconidial strains of fungi of the genus Fusarium, causative agents of root rot and rot of the core of apple fruits.

The work studied the effect of microbiological drugs registered on an apple tree to control scab, powdery mildew, moniliosis: Rizoplan, Liq. (titer 1 billion CFU/ml Pseudomonas fluorescens strain AP-33), Alirin B, WP (titer not less than $10^{9} \mathrm{CFU} / \mathrm{g}$ Bacillus subtilis, strain B-10 FSBSI VIZR), Fitosporin- M, P. (titer of at least 1 billion living cells and spores/ml Bacillus subtilis strain $26 \mathrm{D})$, Vitaplan, WP (titer $10^{10} \mathrm{CFU} / \mathrm{g}$ Bacillus subtilis strain BKMB-2604D, titer $10^{10} \mathrm{CFU} / \mathrm{g}$ Bacillus subtilis strain BKM-B-2605D), as well as promising preparations for use on the apple tree Trichocin, WP (titer $10^{10} \mathrm{CFU} / \mathrm{g}$ Trichoderma harzianum, strain G-30 FSBSI VIZR) and Biocomposite, Liq. (titer not less than $1 \times 10^{9}$ $\mathrm{CFU} / \mathrm{ml}$ strains and metabolites of live bacteria). Control - distilled, autoclaved water; the standard was a fungicide of chemical origin Zimoshans, SC (carbendazim $500 \mathrm{~g} / \mathrm{l}$ ).

Antifungal activity of biological products against fungi of the genus Fusarium was determined by bacto-streep method with joint splicing on PGA medium (potato-glucose agar). Inoculation of double cultures was carried out under sterile conditions simultaneously in triplicate. After 7 days of incubation at a temperature of $25^{\circ} \mathrm{C}$, the growth of the pathogen 
in diameter $(\mathrm{mm})$ was noted in all variants of the experiment, and the biological efficiency was calculated. The types of interactions between cultures were assessed according to generally accepted methods [21-22].

\section{Results and discussion}

As a result of the studies carried out in laboratory conditions, it was found that the studied biological preparations showed both high - 60-90\%, and very low $-20 \%$ or less - biological activity against strains of fungi of the genus Fusarium (table 1). In general, the effectiveness of biologicals was lower the effectiveness of a chemical standard, which suppressed all pathogens by $100 \%$. Of all the studied biological products, only Trichocin, WP had high values of biological effectiveness against almost all strains of the pathogen, with the exception of strain 3, the biological effectiveness against which was insufficient. It should be noted that in relation to this strain, none of the studied biofungicides showed high efficiency; the drugs Biocomposite, Liq. and Rizoplan, Liq. had the lowest values. Both of these preparations also showed a biological efficacy of less than $54 \%$ for all Fusarium strains. For the rest of the drugs, the biological effectiveness varied within a wide range of values depending on the strain.

Table 1. Influence of biologieson the growth of fungi of the genus Fusarium in vitro, 7th day after inoculation

\begin{tabular}{|c|c|c|c|c|c|c|c|}
\hline \multicolumn{2}{|c|}{ Strain } & Alirin B & & Phytosporin- & Rhizopla & Trichoci & Vitap \\
\hline & & \multicolumn{6}{|c|}{ Biological effectiveness, $\%$} \\
\hline \multirow{3}{*}{ 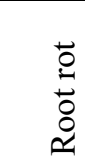 } & 1 & 56.6 & 29.6 & 35.0 & 35.0 & 71.6 & 66.3 \\
\hline & 2 & 21.2 & 42.5 & 57.5 & 48.0 & 65.7 & 54.6 \\
\hline & 3 & 58.6 & 8.0 & 30.3 & 5.5 & 50.5 & 38.3 \\
\hline \multirow{2}{*}{ 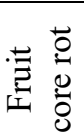 } & 5 & 15.7 & 53.7 & 66.0 & 49.2 & 70.8 & 22.3 \\
\hline & 6 & 85.0 & 12.5 & 20.9 & 15.3 & 90.0 & 20.2 \\
\hline
\end{tabular}

Different types of reactions have been established between pathogens of the genus Fusarium and drug antagonists.

Of the six tested drugs, three showed the greatest antagonistic activity against the pathogen strain 1: Alirin B, WP, Vitaplan, WP and Trichocin, WP. The culture of the pathogen under the influence of these drugs changed its morphological and cultural characteristics; an almost complete absence of the development of aerial mycelium was noted. Perhaps this indicates the death of the mycelium of the test object as a result of contact with the antibiotic substance. Fungistatic antibiotic antagonism was found in the Trichoderma harzianum strain of the drug Trichocin, WP. The lowest efficiency (29\%) was shown by the drug Biocomposite, Liq.

The greatest biological effectiveness against strain 2 was shown by Vitaplan, WP and Trichocin, WP, as well as Fitosporin-M, P (54-65\%), and the least - Alirin B, WP (21\%), however, inhibition of the growth of the pathogen was observed upon contact with the antagonist of this drug. It should be noted that in the variants with the drugs Rizoplan, Liq. and Biocomposite, Liq. the shape of the colony (to irregular) and the edge of the colony of 
the fungus culture (to wavy) changed. For the antagonist of the drug Trichocin, WP and the pathogen, mutual suppression on contact was found; after a while, the antagonist continues to grow at a constant or lower rate over the colony of the suppressed organism.

Overall, the biologics showed the most significant antifungal activity and efficacy on strains 1 and 2.

Strain 3 turned out to be the fastest growing culture in the experiment. The cultural characteristics of the strain did not change, the aerial mycelium of the pathogen in double cultures developed normally. With regard to the drug Trichocin, WP the spectrum of interactions was limited by competition for nutrition sources and area, and the antagonistic activity was 0 points; cultures were characterized by mixed growth.

For strain 4, when co-cultivated with biological products, after 7 days, the maximum efficiency was $66-70 \%$ for Fitosporin-M, P and Trichocin, WP, and the latter showed mutual suppression upon contact. In the variant of the experiment with Biocomposite, Liq. the fungal strain changed the shape and edge of the colony. The minimum efficacy was for Alirin B, WP and Vitaplan, WP and was less than $20 \%$.

Strain 5 was the slowest growing culture in our sample and on the 7th day of growth had a diameter of $40 \pm 5 \mathrm{~mm}$. In this variant of the experiment, the greatest BE was recorded: 85 $90 \%$ for the drugs Alirin B, WP and Trichocin, WP. And besides, in Trichoderma harzianum, strain G-30 VIZR, maximum hyperparasitism was found; and in bacteria - fungistatic antibiotic antagonism, the growth of the pathogen colony was inhibited at a distance, with the formation of an obvious "sterile" zone between them. For other drugs, the effectiveness was less than $20 \%$. A change in the color of the culture was noted in the variants with the preparations Alirin B, WP, Trichocin, WP and Fitosporin-M, P.

It should be noted that the relationship we have recorded between pathogenic strains of the genus Fusarium and antagonistic strains of biological products was noted by a number of researchers [21-22].

\section{Conclusion}

As a result of the study of the antifungal activity of microbiological drugs against fungi of the genus Fusarium, causative agents of rot of roots and fruits of the apple tree, both weak and very strong mycoparasitism were noted, but in most variants of the experiment, competition for the area of nutrition prevailed. Under the influence of some drugs, the shape, edge and color of the fungus colony changed.

Primary laboratory screening showed that out of 6 selected microbiological preparations against root rot pathogens showed high and medium efficiency Trichocin, WP, Alirin B, WP and Vitaplan, WP; Rizoplan, Liq. and Biocomposite, Liq. did not have the effectiveness. Trichocin, WP, Alirin B, WP were effective against pathogens of fruit core rot; Rizoplan, Liq. and Vitaplan, WP showed low efficiency.

In general, for the entire sample of pathogens, the best bioagents were the antagonists of the drug Trichocin, WP, which suppressed all five strains with BE 50-90\% and showed hyperparasitism in one strain, as well as the drug Alirin B, WP, which inhibited the growth of three strains with BE $56-85 \%$, showing antibiosis or fungistatic antibiotic antagonism with the formation of a "sterile" zone.

\section{References}

1. F. Naz, A. Tariq, C.A. Rauf, T. Sultana, J. Plant Path., 100, 589 (2018) https://doi.org/10.1007/s42161-018-0093-Z 
2. S. Mannai, N. Horrigue-Raouani, N. Boughalleb-M'Hamdi, J. Biol.1 Stud., 1(2), 14-34 (2018) https://onlinejbs.com/index.php/jbs/article/view/7

3. W. Gongshuai, Y. Chengmiao, P. Fengbing, W. Xiaobao, X. Li, W. Yanfang, W. Jinzheng, T. Changping, C. Jie, M. Zhiquan, Hortic. Plant J., 4(5), 175-181 (2018) https://doi.org/10.1016/j.hpj.2018.05.003

4. I.L. Astapchuk, G.V. Yakuba, A.I. Nasonov, BIO Web of Conferences, 25, 06002, (2020) https://doi.org/10.1051/bioconf/20202506002

5. I.L. Astapchuk, G.V. Yakuba, A.I. Nasonov, BIO Web of conferences, 7, 00005 (2020) https://doi.org/10.1051/bioconf/20202100005

6. I.L. Astapchuk, G.V. Yakuba, A.I. Nasonov, E3S Web of conferences, 285, 03015 (2021) https://doi.org/10.1051/e3sconf/202128503015

7. G.V. Yakuba, I.L. Astapchuk, A.I. Nasonov, Tavrichesky bulletin of agrarian science, 2 (22), 188-197 (2020) http://doi.org/10.33952/2542-0720-2020-2-22-188-197

8. F. Essl, B. Lenzner, S. Bacher, Global Change Biology, 26(9), 4880-4893 (2020) https://doi.org/10.1111/gcb.15199

9. T.Yu. Gagkaeva, O.P. Gavrilova, A.I. Kuzin, N.I. Kuznetsova, M.A. Nikolaenko, R.R. Azizbekyan. Russian Journal of Biotechnology, 1, 32-37 (2014) http://eng.genetika.ru/journal/archive/55/56/369/

10. T. Akhtar, Q. Shakeel, G. Sarwar, S. Muhammad, Pakistan Journal of Botany, 49(2), 769774 (2017) https://www.researchgate.net/publication/315803168

11. A.E. Stanchuk, D.V. Voitka, Biologically active preparations for plant growing, Proceedings of the XIV International scientific-applied conference, 145-147 (2020) https://elib.bsu.by/bitstream/123456789/252840/1/145-147.pdf

12. P. Martinez-Alvarez, F.M. Alves-Santos, J.J. Diez, Silva Fennica, 46 (3), 303-316 (2012) http://doi.org/10.14214/sf.42

13. N. Chaves, C. Staver, M. Dita, Acta Hortic., 1114, 261-266 (2014) http://doi.org/10.17660/ActaHortic.2016.1114.35

14. A. Martínez-Medina, A. Roldán, J.A. Pascual, Hort. Sci., 44(7), 2025-2027, (2009) https://doi.org/10.21273/HORTSCI.44.7.2025

15. O.T. Shainidze, A.D. Murvanidz, Eurasian Union of Scientists, 6(27), 107-111 (2016) https://www.researchgate.net/publication/338501974_Biologiceskie metody_borby_pro tiv_vozbuditela_cernoj_kornevoj_gnili_EVRAZIJSKIJ_SOUZ_UCENYH_ESU_Mosk va 2016

16. M.H. Aydin. Applied ecology and environmental research, 17(1), 533-546 (2019) http://doi.org/10.15666/aeer/1701533546

17. N. Anjum, A.A. Shahid, S. Iftikhar, M. Mubeen, Plant Cell Biotech. Mol. Biol., 21(5960), $42-57$ (2020) https://www.researchgate.net/publication/346528816

18. L.V. Maslienko, A.Kh. Voronkova, L.A. Datsenko, E.A. Efimtseva, Oilseeds, 1(181), 108-113 (2020) http://doi.org/10.25230/2412-608X-2020-1-181-108-113

19. M. V. Shternshis, A. A. Belyaev, T. V. Shpatova, A. A. Lelyak, Microbial biotechnology, 7, 135-136 (2015) http://mbio.bas-net.by/wp-content/uploads/2015/09/thesis-InMi2015.pdf

20. M.V. Shternshis, Tomsk State University Journal of Biology, 2(18), 92-100 (2012) http://journals.tsu.ru/biology/en/\&journal page=archive\&id=757\&article id=31122

21. A.D. Popova, V.S. Sadykova, International Research Journal, 5(1), 33-35 (2014) http://research-journal.org/wp-content/uploads/2011/10/5-1-24.pdf

22. L.V. Maslienko, A.Kh. Voronkova, L.A. Datsenko, Proceedings of the Kuban State Agrarian University, 78, 91-98 (2019) http://doi.org/10.21515/1999-1703-78-91-98 